\title{
BRIEF COMMUNICATION IMMUNE RESPONSE AND SEVERITY OF PULMONARY TUBERCULOSIS IN CHILDREN
}

\author{
Clemax Couto SANT'ANNA (1), Mônica A. Saad FERREIRA (2) \& Leila de Souza FOnSECA (2).
}

KEYWORDS: ELISA; Pulmonary tuberculosis; Children

M. tuberculosis has a particular antigenic constitution and tuberculosis is a disease with a great interpersonal variability in its clinical presentation. Immune humoral response in tuberculosis is not yet completely clear ${ }^{6}$. ELISA is one of the most studied serological techniques ${ }^{3,8}$, using PPD as an antigen. $\mathrm{IgG}$ antibodies are generally detected showing higher levels in patients with active disease.

In Brazil, FONSECA et al. ${ }^{4}$ observed a increase in antibody titers in more advanced forms of the disease, mainly in pediatric patients.

In the present study forty eight children of low income families, with ages ranging from 0 to 13 years, both male and female, were separated in two groups: 1) Children with tuberculosis $(\mathrm{n}=29)$; 2) Children without tuberculosis (contacts of patients with tuberculosis $(n=19)$. The 19 chest radiographs in Group 2 were considered as normal. The diagnosis of tuberculosis was established based on positive culture of M. tuberculosis from gastric aspirates and also in cases of supposedly bacterial pneumonia, treated up to 15 days with antimicrobial drugs (adequate to cover the most common etiological agents), with unsatisfactory response to the treatment, in children who had had contact with a bacillpher adult.

All patients were submitted to Mantoux TST using 0.1 ml (2 UT) of Rt 23 PPD $^{2}$.

Gastric aspirate material was collected in all patients in two subsequent days and then submitted to bacilloscopy and culture for $M$. tuberculosis using the Loewstein-Jensen conventional method. Seventeen patients had positive results.
The presence of $\operatorname{IgG}$ anti-PPD antibodies in serum samples was investigated in both groups. IgG anti-PPD antibodies were researched using ELISA, PPD Rt-23 at a concentration of $10 \mathrm{ng} / \mathrm{ml}$, anti-IgG B-galactosidase conjugate at 1/1000 dilution (Biosys, Compiégne, France) with serum tested at 1/160 dilution in all children from both groups, according SAAD et al. ${ }^{5}$ The cut-off value for the Elisa was absorbance at $405 \mathrm{~nm}=0.09$, which was two standard deviations above the mean obtained for the health children. Each patient serum was clearly identified and frozen until the test.

We adopted 3 categories in radiological classification: primary complex tuberculosis (less severe), pulmonary tuberculosis (mild) and milliary (severe), that we have already adopted in previous studies, in accordance to others authors ${ }^{7}$.

No statistical differences between O.D levels of ELISA tests as related to age, tuberculin skin test and BCG vaccination were found in both groups. These are similar to the results of ALDE et al. ${ }^{1}$ However, the analysis of radiological pattern and O.D values in the ELISA test showed that these values were higher in patients with milliary pattern. Intermediate O.D values were found in cases of pulmonary tuberculosis and lower O.D. values in the primary complex pattern $(\mathrm{p}<0.05)($ Table 1$)$.

The analysis of O.D. values and the radiological presentation in all 48 children of our study shows that the average values range from low values - 0.026 - in children with normal radiographs (Group 2); to intermediate values 0.080 and 0.099 - in primary complex and pulmonary patterns, respectively, to the highest values -0.172 - in milliary pattern $(\mathrm{p}<0.05)$.

(1) Departamento de Pediatria da Faculdade de Medicina da Universidade Federal do Rio de Janeiro (UFRJ). Instituto de Puericultura e Pediatria Martagão Gesteira, Rio de Janeiro, RJ, Brasil.

(2) Instituto de Microbiologia. Bloco 1, Centro de Ciências da Saúde, Rio de Janeiro, RJ, Brasil.

Correspondence to: Clemax C. Sant'Anna, R. Sá Ferreira 159 ap. 402, Copacabana, 22071-100 Rio de Janeiro, RJ, Brazil. 
SANT'ANNA, C.C.; FERREIRA, M.A.S. \& FONSECA, L. de S. - Immune response and severity of pulmonary tuberculosis in children. Rev. Inst. Med., trop. S. Paulo, 40(2): 123-124, 1998.

\section{TABLE 1}

Serological test: evaluation of optical density (O. D) average values, age, tuberculin skin test, BCG vaccinal status and radiological patterns in Group 1.

\begin{tabular}{lccc}
\hline \multicolumn{1}{c}{ Variable } & N & $\begin{array}{c}\text { O.D } \\
\text { average }\end{array}$ & $\begin{array}{c}\text { P } \\
\text { value }\end{array}$ \\
\hline Age & 8 & 0.151 & \\
Age $<$ 1 year & 13 & 0.091 & \\
Ages 1 to 3 years and 11 months & 7 & 0.103 & \\
Ages 4 to 9 years and 11 months & 1 & 0.161 & n.s \\
Ages $\geq 10$ years & & & \\
Tuberculin Skin Test & 12 & 0.106 & \\
Negative & 3 & 0.213 & \\
Weakly positive & 12 & 0.079 & n.s \\
Strongly positive & & & \\
BCG Vaccination & 13 & 0.139 & \\
Yes & 12 & 0.088 & \\
No & & & \\
Radiological Patterns & 12 & 0.099 & \\
Pulmonary tuberculosis & 9 & 0.080 & \\
Primary complex tuberculosis & 8 & 0.172 & $<0.05$ \\
Milliary & & & \\
\hline
\end{tabular}

FONSECA et al. $^{4}$ in previous study in 1992 already state a direct correlation between tuberculosis severity and high levels of the serological tests. The present data support the concept of a positive relationship between humoral immune response and severe and extensive forms of pulmonary tuberculosis in children.

\section{ACKNOWLEDGEMENTS}

We are grateful to Dr. Afranio Kritski, Prof J. Uéleres Braga, Dr. Mario José Marques, Dr. Marilene A. Rocha Santos and also to Prof. Maria José Conceição and Prof. Léa
Camillo-Coura (coordinators of Curso de Pós-graduação em Doenças Infecciosas e Parasitárias da Faculdade de Medicina da Universidade Federal do Rio de Janeiro) for technical assistance and encouragement.

\section{REFERENCES}

1. ALDE, S.L.M.; PIÑASCO, H.M.; PELOSI, F.R. et al. - Evaluation of an enzyme linked immunosorbent assay (ELISA) using an IgG antibody to $M$. tuberculosis antigen 5 in the diagnosis of tuberculosis in children. Amer. Rev. resp. Dis., 139: 748-751. 1989.

2. BRASIL. Ministério da Saúde - Manual de normas para o controle da tuberculose. Brasília, 1995.

3. ENGVALL, E. \& PERLMAN, P. - Enzyme-linked immunosorbent assay (ELISA): quantitative assay of immunoglobulin G. Immunochemistry, 8: 871,874, 1971.

4. FONSECA, L.S.; KRITSKI, A.; SANT'ANNA, C.C. et al. - Relationship between immune response and clinical manifestations in patients with tuberculosis. Braz. J. med. biol. Res., 25: 49-52, 1992.

5. SAAD, M.H.F.; KRITSKI, A.L.; BARROSO, E.W. et al. - Use of the 2,3-Diacyl-trehalose and purified protein derivative in the serodiagnosis of tuberculosis in AIDS. Mem. Inst. Oswaldo Cruz, 91: 97-100, 1996.

6. SADA DIAZ, E. - Inmunologia de tuberculosis: metodos diagnosticos. In: SEMINARIO REGIONAL DE TUBERCULOSIS, 4., Washington, OPAS/OMS, 1988. p. 36-44. (Publ. Cient. No. 511)

7. SANT'ANNA, C.C. - Formas clínico-radiológicas. In: SANT'ANNA, C.C. \& BETHLEM, N., ed. Tuberculose na infância. 2. ed. Rio de Janeiro, Cultura Médica, 1988.

8. WAN WEEMAN, B.K. \& SCHUURS, A.H.M - Immunoassay using antigen-enzyme conjugates. FEBS Lett., 15: 232-236, 1971.

Recebido para publicação em 23/10/1997

Aceito para publicação em 12/02/1998 